\title{
Correlation Among Morphological Characters of Local Sweet Potato (Ipomea batatas L.) Accessions in Kerinci Regency
}

\author{
Sosiawan Nusifera ${ }^{1, *}$ Yulia Alia ${ }^{2, *}$ Agus Kurniawan Mastur $^{3}$ \\ ${ }^{1,2,3}$ Agroecotechnology Department of Agricultural Faculty, University of Jambi, Indonesia \\ * Author for correspondence: sosiawan_nusifera@unja.ac.id
}

\begin{abstract}
Sweet potato is one of starchy tuber crop with high potential as a source carbohydrate for both food and feed. Developing this crop through breeding program requires clear understandings on correlative relationships among plant characters especially when indirect selection scheme is used. This research was aimed to know the correlation among morphological characters on sweet potato accessions originated from Kerinci Regency. The research was initiated by exploration and accession collection in several district regions where sweet potato crops were found. Such collected accession was planted in a randomized block design using one row plot with two replications. Characters observed were several morphological characters referring to plant descriptor issued by Center for Plant Variety Protection. Data were analyzed using descriptive statistics (diversity index) and a non-parametric correlation analysis (Spearman-rho). Results showed that several morphological characters were intercorrelated each other both positively and negatively. This meant such characters could be used as a secondary trait in selecting potential genotypes for specific purposes through indirect selection scheme of breeding.
\end{abstract}

Keywords: Accession, Correlation, Kerinci, Morphological characters, Sweet potato.

\section{INTRODUCTION}

Sweet potato is starchy tuber crop which plays significant role for people in many developing countries; the tropics, sub-tropics and warm temperate regions of the world. These are due to its high productivity and its abundant uses both as source of food and feed, both freshly consumed and processed food.

Apart from its starchy characteristic, sweet potato can be consumed to meet the need of vitamin $\mathrm{A}, \mathrm{Zn}, \mathrm{Fe}, \mathrm{Ca}$ and $\mathrm{K}$ as well as antioxidant [1]. Nowadays, sweet potato has been an alternative source of carbohydrate in achieving food security through food diversification program. Therefore, due to increased number of populations, demand of sweet potato also increases every year [2].

Increasing demand of sweet potato surely has consequences in the necessity to increase production. Among any efforts of increasing production such as cultivation techniques and extending planting area, genetic engineering through well planned breeding program has offered great promising opportunities since
Indonesia has great potential of plant genetic resources to be improved.

Indonesia has abundant sweet potato local germplasms distributed in various region with ranged and various ecogeographic environment. One of such regions is Kerinci Regency of Jambi Province which is considered to one of sweet potato production center in Jambi Province. Such varied range of ecogeographic environment in Kerinci can be considered as an indicator that genetic variation is there [3]. Rao dan Hodgkin [4] stated that ranged ecogeographical environment is one of causes of genetic differentiation and variability of plant species.

Crop improvement through a breeding scheme generally involve selection in any stage of the process. Selection is aimed to narrow down the variability in order to achieve a genotype with desired characters. Selection can be divided into direct and indirect selection. Association or correlation information are often needed in applying selection scheme.

Information on the nature and magnitude of correlations of economic traits in sweet potato is 
important for direct or indirect selection for improvement of the crop. It facilitates selection for complex traits with low heritability via other traits that are highly correlated with yield and have high heritability values. Significant correlations among traits influence the selection progress positively or negatively. Knowledge on the number of desired traits to be evaluated and magnitude of their correlations is important to breeders for simultaneous selection and to enhance selection gains. Furthermore, correlation analysis is the basis for establishing a selection index during selection.

Yield or tuber weight, for instance, is a quantitative character which its genotypic expression is greatly influenced by environmental factors and therefore low heritability. Selecting for higher yielding genotype sometimes takes longer due to its low selection response or genetic gain. In order to achieve higher genetic gain, selection secondary trait which is genotypically and phenotypically correlated with yield will be required. Several researches revealed that there were association among morphological characters and between morphological characters with yield, yield component and tuber quality characters ([5][6] [7]). Therefore, such study to know interrelationship among morphological characters will be required for genetic improvement Kerinci local germplasm of sweet potato.

\section{MATERIAL AND METHOD}

This research comprised two sections. First section were exploration and collection of accessions and the second was evaluation of accession performance. Exploration was conducted in march 2020 in several district region in Kerinci Regency. Location map were displayed in figure 1. Whereas, evaluation of performance was conducted in Bengkolan Dua Village, Gunung Tujuh District started from April 2020 until September 2020. Material used were twenty sweet potato accessions collected from various region in Kerinci Regency.

This research was an experimental research arranged in a randomized block design with two replications. Treatment factor was sweet potato accessions comprised twenty levels. Each accession was planted in a one row plot consisted of ten plants. The plots were spaced $60 \mathrm{~cm}$ and $30 \mathrm{~cm}$ within row in a plot. Characters observed were morphological characters and were measured referring to sweet potato descriptor issued by Center of Plant Variety Protection (2007).

Data observed were analyzed descriptively and quantitatively. Variability of character performances was estimated using parameter of relative diversity index $(\mathrm{J})$ [8] with formula as followed.

\section{$\mathbf{J}=\mathbf{H}^{\prime} / \mathbf{H}^{\prime}$ maks}

Remarks : H' $=-\Sigma P i L n$ Pini=1, H'maks $=\ln \mathrm{n}, P$ $=$ trait frequency
Such index was utilized to analyzed phenotypic data of qualitative characters. Degree of genetic variability of each morphological character based on diversity index was determined according to relative criteria namely very narrow, narrow, wide, and very wide. Such criteria were determined by dividing range of diversity index with class number in order to get class interval [9].

Association among variables observed were analyzed quantitatively using a Spearman-Rho non parametric correlation [10].

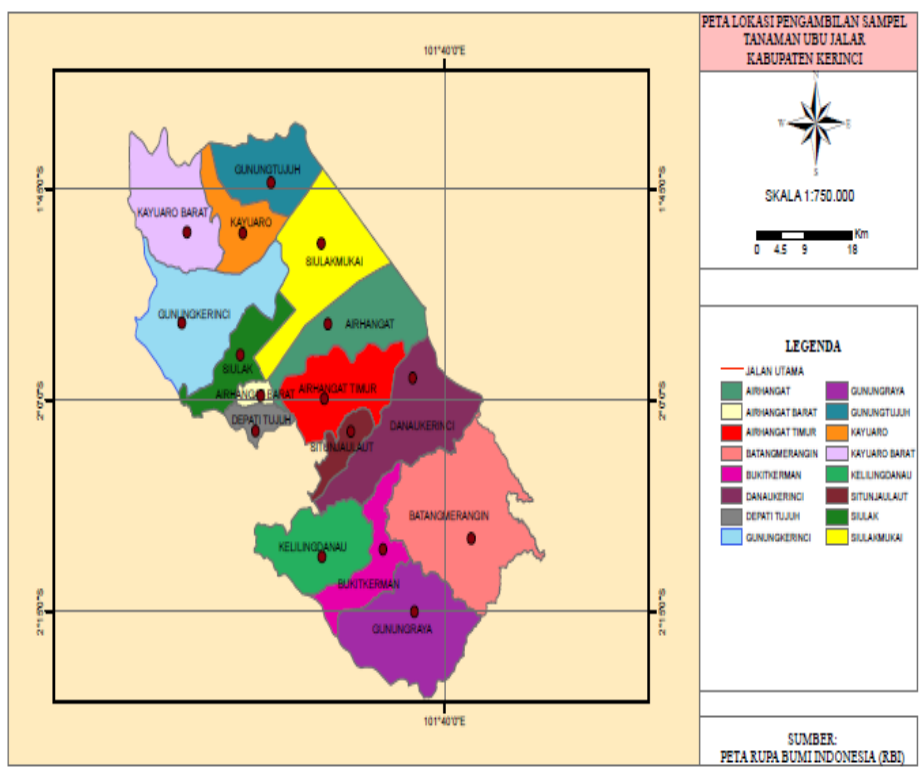

Figure 1 Location map of sweet potato accession collection in Kerinci Regency

\section{RESULTS AND DISCUSSIONS}

\subsection{Phenotypic Variation of Morphological Characters}

Sweet potato accessions evaluated were resulted from collection trip in several regions in Kerinci Regency which their ecogeographical environment were relatively diverse. That was why it was assumed to have wide genetic variation. Results of evaluation showed that twenty accessions had considerably wide variability of morphological characters. Variation of phenotypic performance for instance, vine characters, growth habits, leave, and tuber characters.

Few examples of such variation were displayed in figures 2, 3, and 4. Whereas, descriptive parameters of morphological characters were displayed in figure 5 . 


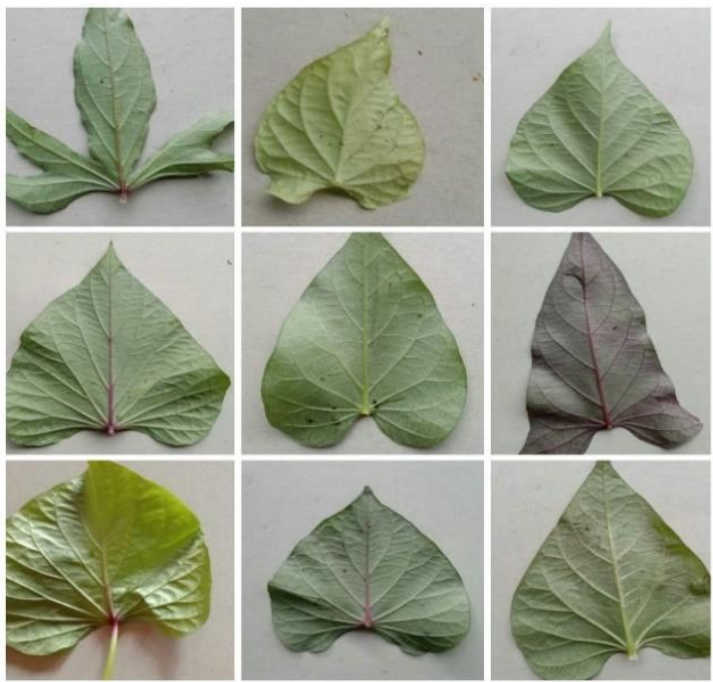

Figure 2 Variation of leaf shape

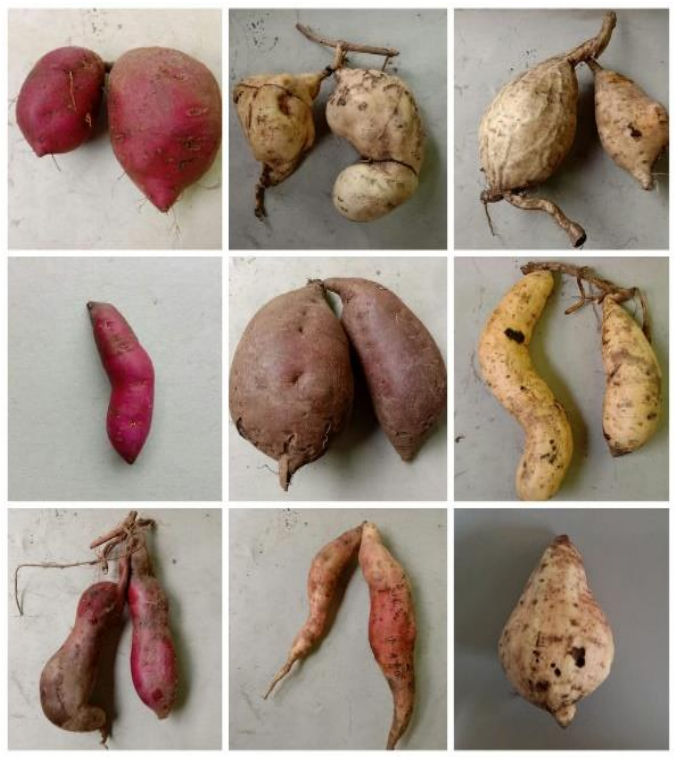

(a)

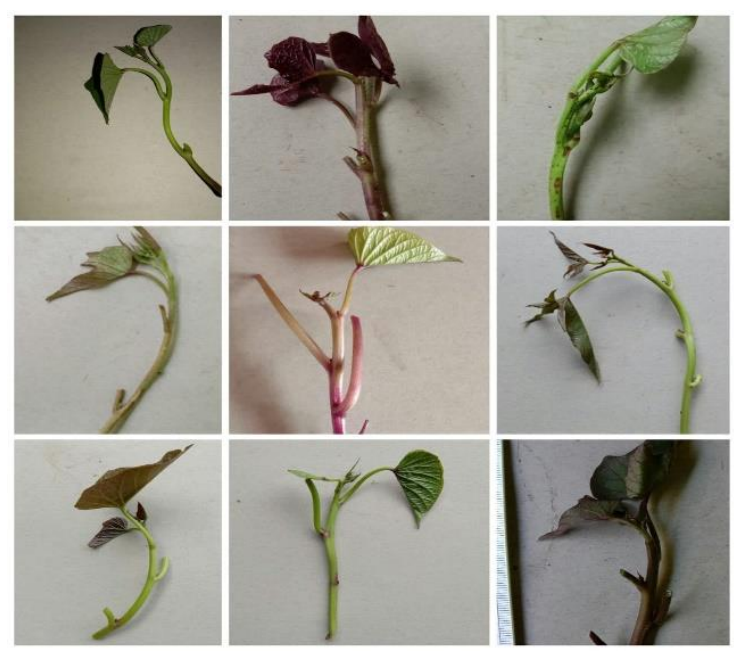

Figure 3 Variation of vine tip color and shape

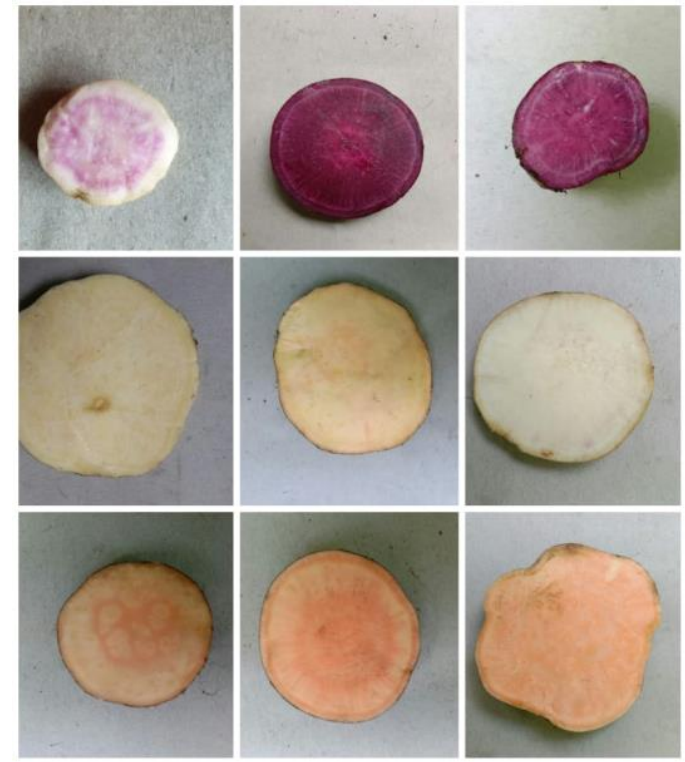

(b)

Figure 4. Variation of tuber shape (a) and color of tuber flesh (b)

In figure 5, it was indicated that twenty accessions evaluated had showed variation of plant type namely semi compact, erect, spreading and extremely spreading. Highest percentage of plant type was seen on semi compact plant type. Based on its diversity index $(\mathrm{J}=$ 0,62 ), plant type variation was categorized as narrow since the population was dominated by semi compact plant type.

Variation of predominant vine color was categorized very wide $(\mathrm{J}=0,94)$ with green, purple, and dark-purple with nearly same percentage. All accessions had purple spots on vine with varied density. Density variation was categorized as very wide $(\mathrm{J}=0,98)$. Only small amount of accessions had dense purple spots while most of them had only few. 

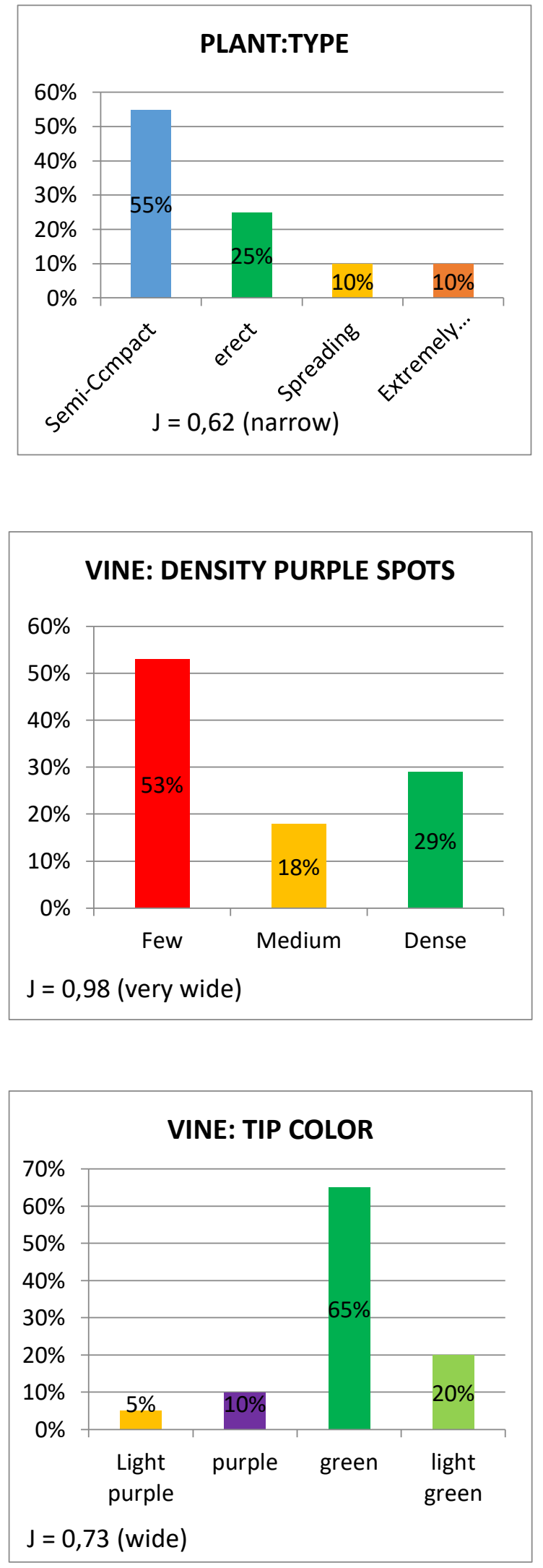
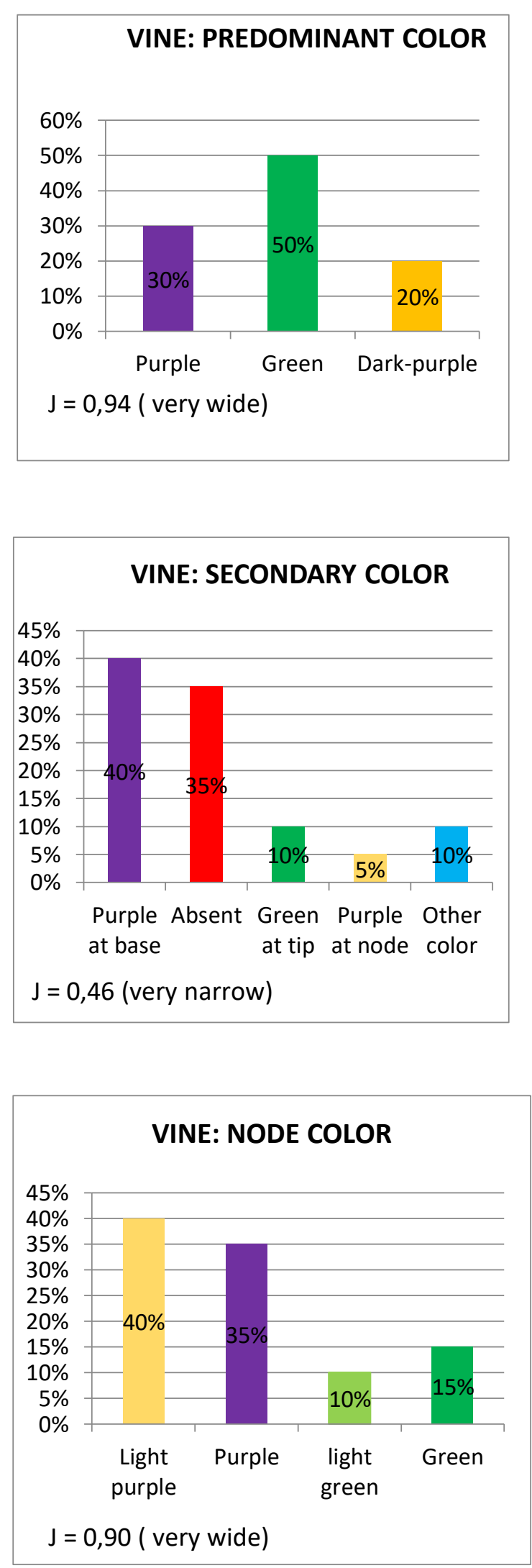

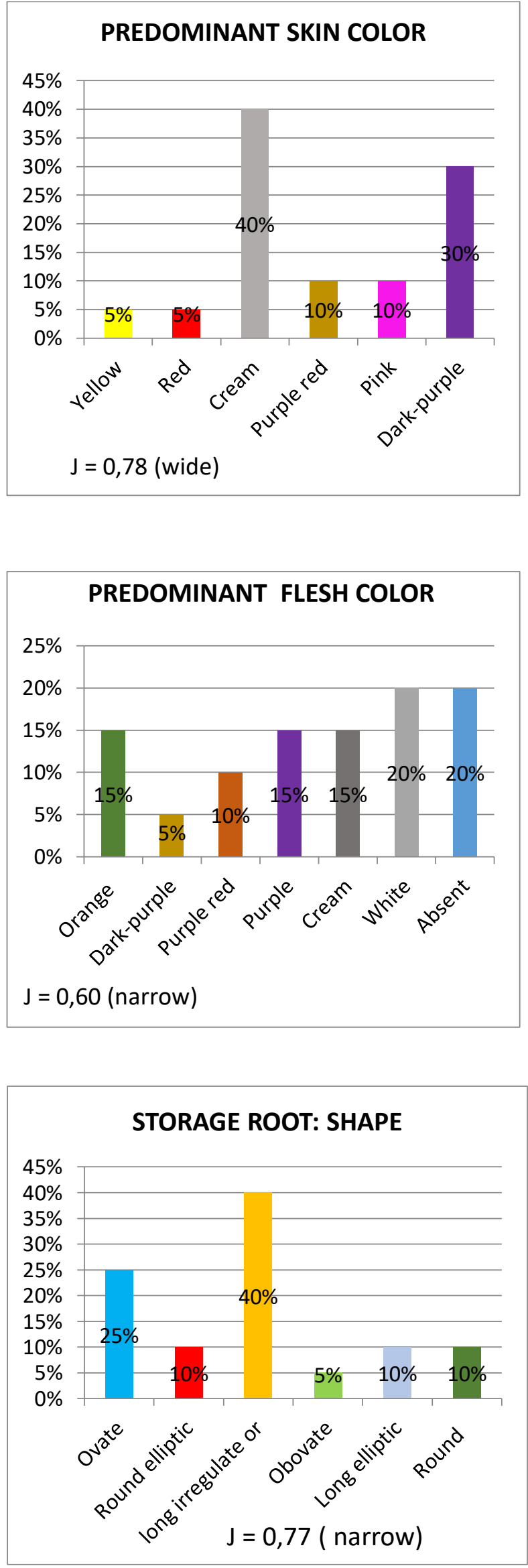
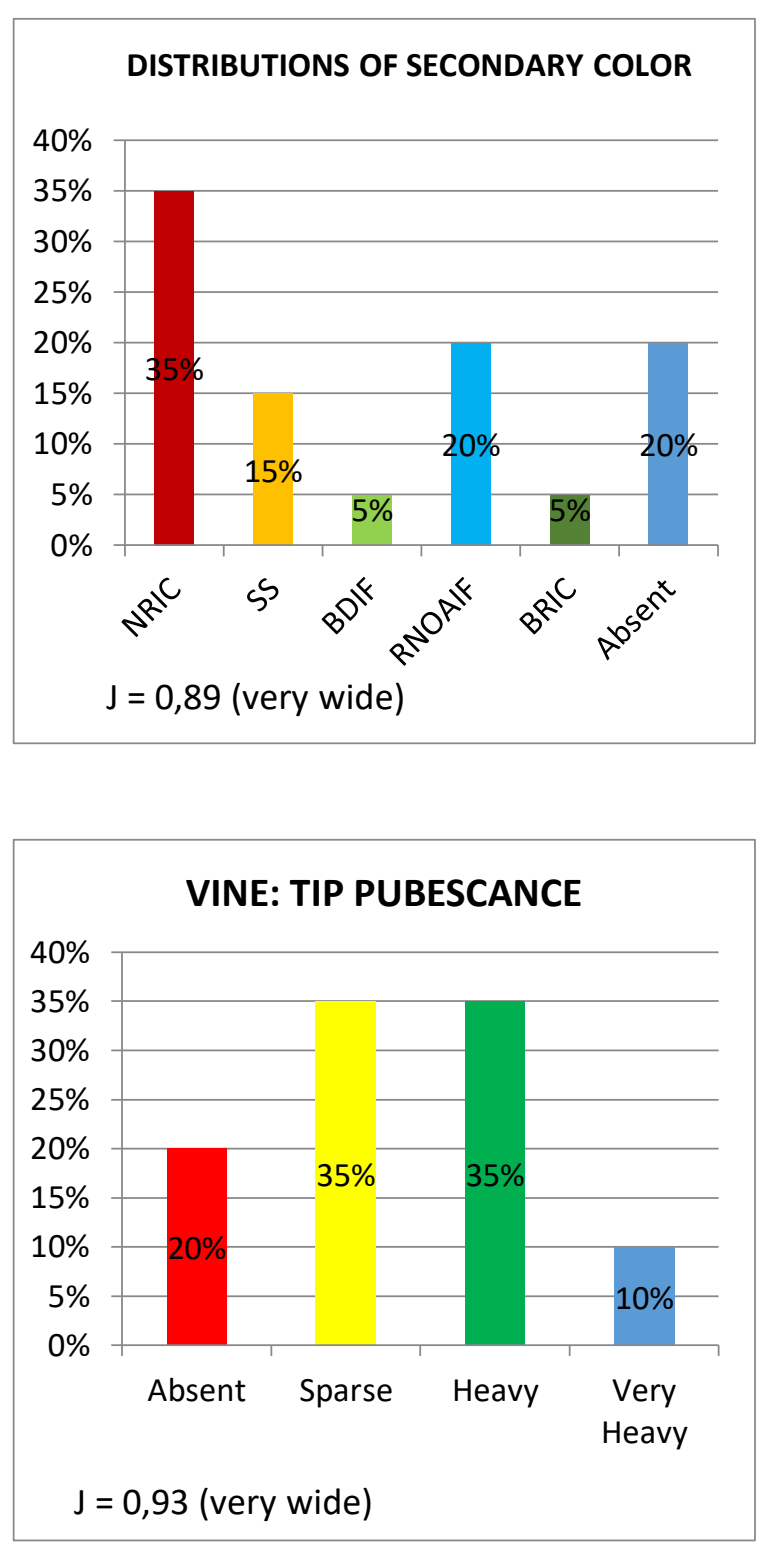

Figure 5. Descriptive statistic of sweet potato morphological characters

Several accessions showed secondary predominant color on vine but many of them did not. Its variation was categorized very narrow $(\mathrm{J}=0,46)$. Likewise, on vine tip color, which was generally green and only small amount purple and light green colored vine tip. Its variation was categorized as wide $(\mathrm{J}=0,73)$. Some of accession showed no tip pubescence, sparse, heavy and very heavy, which were equally distributed in population. Variation of tip pubescence was categorized as very wide with $\mathbf{J}$ value $=$ 0,93. Apart from that, node color of most accession was light purple while the rest were light green, green and purple. Variation of node color was categorized as wide with diversity index $(J)=0,90$.

Most of accessions had triangular shaped leaf, while the rest hastate shaped, lobe, cordate and almost divide with proportional number. Most of accession had long 
irregulate shaped tuber while the rest were ovate, round elliptic, obovate, long elliptic, and round. Most of predominant skin color of tuber were cream, while the rest with small percentage were dark purple, yellow, purple-red, and pink. Most tuber had secondary color namely white, orange, purple-red, and cream with equal proportion, and smallest percentage was dark purple. Such secondary color was distributed in various pattern namely narrow ring in cortex with highest percentage, followed by ring in the middle of flesh, scattered spots, and covering most of the flesh.

\subsection{Correlation among morphological characters in sweet potato}

Results of correlation analysis showed that there were intercorrelation among several morphological characters of Kerinci sweet potato accessions. Correlation coefficient were displayed in Table 1. Plant type showed to have negative correlation with leaf shape and positive with vine tip color. Plant tended to spread would have rounded leaf shape. In contrast, the more erect tended to have more separated leaf shape. Vine dominant color had positive correlation with vine density purple spots, vine tip color and vine node color. Purple tendency of vine dominant color would tend to have purple vine tip and node color, as well as purple dot density which positively correlated with vine tip and vine node color

Predominant color tuber skin had positive correlation with predominant color of tuber flesh. Purple tuber skin would tend to have purple tuber flesh dominant color. On the other hand, morphological characters showing positive correlation with tuber weight was secondary vine color, and negative correlation was tuber shape. Vine with purple secondary color both on node and tip would tend to have heavier tuber weight. Whereas, tuber weight with rounded shape tended to be heavier compared with long shaped tuber.

\subsection{Discussions}

Results showed that morphological characters of Kerinci sweet potato accessions had considerably wide variability. This fact might be caused by distribution of ecogeographical environment of location where they were collected, introduction, or intercrossing among plant individual [11].

Specific characteristics of ecogeographical environment had influenced genetic expressions process which in turn induced changed of physiological process and eventually brought change in phenotypic performances. Such Phenotypic changes could be one of adaptation features which was physiological at the beginning and sooner or later became genetically changed. Coates dan Byrne [11] and Qiu et al., [12] explained that stress due to ecogeographical environment during adaptation process had resulted in micro mutation. Consequently, new genotype with specific adaptability was created for such environment. In line with that, Frison et al., (2010)[15] stated that ecogeographical environment stress during adaptation process in long period might cause micro evolution so that genetic diversity increased.

As well as mutation factor, increased genetic diversity could be due to segregation factor. Segregation in heterozygotic individual derived from crossed fertilized could bring about new genotypes as a result of genetic combination from both parents, moreover when transgressive segregation took place [14].

On the other hand, several morphological characters showed linear variation one another or intercorrelation. Such correlation, basically could be phenotypic and genotypic. Phenotypically correlated characters resulted from genetic association among controlling genes interfered by environmental factors or could be caused by environmental itself.

Genotypically, degree of linearity of association among two characters or more was determined by two molecular situations namely gene linkage and pleiotropy effect 15]. Gene linkage is any situation where a gene or allele controlling two different traits bound to same chromosome whereas pleiotropy was a phenomenon where an allele or gen in a locus controlled two or more characters or traits [16]. Correlated characters in this sweet potato research were in accordance with previous reported researches $([5][6][7]$.

Information of correlated characters could be utilized in selection process of plant breeding program of sweet potato. Characters or traits desired in breeding program often had low heritability value or other obstacles in doing selection. Such situation could generally be overcome through indirect selection scheme, selection of one character through another characters. Based on information from this research, selection for heavier tuber weight could be undertaken by selecting characters of vine color and tuber shape.

\section{CONCLUSIONS}

Twenty Ker inci sweet potato accessions evaluated showed varied performances of morphological characters ranging from narrow to very wide variability. Several morphological characters were found to have interrelationship both negatively or positively, while the rest were not.

Morphological characters showing positive correlation with tuber weight was secondary vine color, and negative correlation was tuber shape. Such correlated characters could be used as secondary trait for indirect selection in breeding program. 


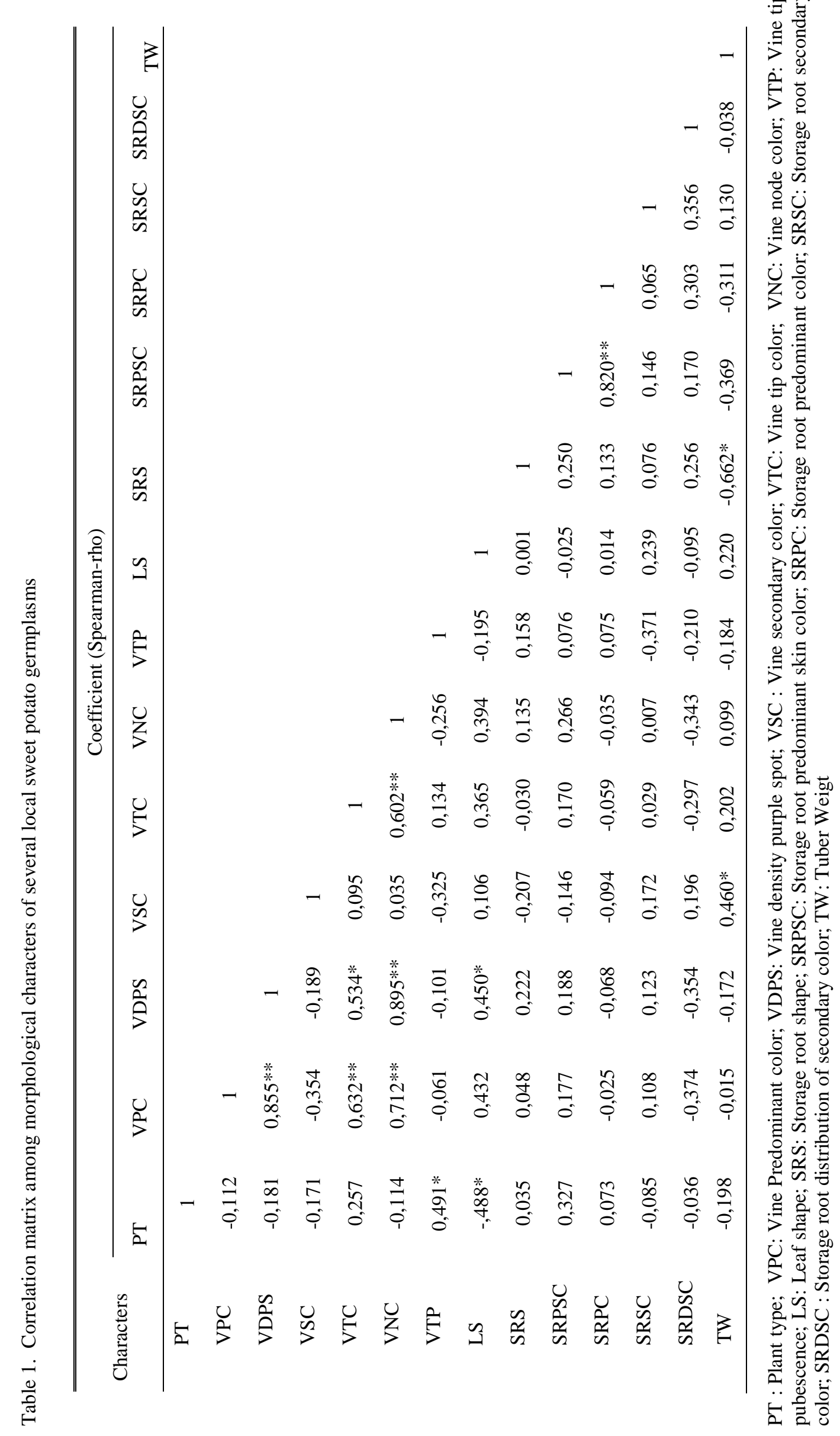




\section{REFERENCES}

[1] Pradhan, DMP, Mukherjee A, George J, Chakrabarti SK, Vimala B, Naskar SK, Sahoo B K, Samal S. 2015. High starch, beta carotene, and anthocyanin rich sweet potato: ascent to future food and nutrition security in coastal and backward areas. Intl J Trop Agric 33 (2): 397400 (Part I).

[2] Wijayati, P D, Harianto, A. Suryana. 2019. Permintaan pangan sumber karbohidrat di Indonesia (The Demand for Carbohydrate Source Food in Indonesia). Analisis Kebijakan Pertanian, Vol. 17 No. 1, Juni 2019:13-26 DOI: http://dx.doi.org/10.21082/akp.v17n1.2019.13-26

[3] Nusifera, S, Y. Alia, A. P. Lestari, M. Maulana. 2020. Diversitas Genetik Populasi Padi (Oryza sativa L.) Payo di Kabupaten Kerinci Provinsi Jambi Berdasarkan Marka Morfologi. Jurnal Agrosaintek, 4 (1) : 61-69

[4] Rao, V.R., and T. Hodgkin. 2002 Genetic diversity and conservation and utilization of plant genetic resources Plant Cell Tissue Organ Cult., 68 (2002), pp. 1-19

[5] Tsegaye, E. S., E. V. Divakara, N. Dechassa . 2006. Correlation and Path Analysis in Sweet Potato and their Implications for Clonal Selection. Journal of Agronomy, 5 (3): 391-395.

[6] Mohanty, P., Rout, M.K, Behera, R.D., Krishi, Kendra, V., and Kendra, K.V. 2016. Character Association and Path Analysis in Sweet Potato (Ipomoea batatas (L.) Lam.) Genotypes. Life Sciences. 5. 441-448.

[7] Gurmu, F., Hussein A Shimelis, and Mark D Laing . 2017. Correlation and path-coefficient analyses of root yield and related traits among selected sweetpotato genotypes. South African Journal of Plant and Soil 2017: 1- 8.

[8] Pielou EC. 1966. The Measurement of Diversity in Different Types of Biological Collections. $J$. Theoret. Biol., 13: 131-144
[9] Maulana M, Nusifera S, Alia Y, Eliyanti. 2019. Variabilitas Karakter Morfologi pada Populasi Padi Payo di Kabupaten Kerinci. Di dalam: Irianto, Junaedi H, Nusifera S, Fathoni Z (Eds) Prosiding Semirata BKS PTN Wilayah Barat Bidang Ilmu Pertanian, Jambi 27 - 29 Agustus 2019.

10] Hauke J, and Kossowski T. 2011. Comparison of values of Pearson's and Spearman's correlation coefficients on the same sets of data. Quaestiones Geographicae 30 (2): 87-93.

[11] Coates DJ, Byrne M. 2005. Genetic Variation in Plant Populations : asessing cause and pattern. In: R.J. Henry (Ed). Plant Diversity and Evolution; genotypic and phenotypic variation in higher plants. CAB International.

[12] Qiu J, Zhou Y, Mao L, Ye C, Wang W, Zhang J, Yu Y, Fu F, Wang Y, Qian F, Qi T, Wu S, Sultana MH, Cao YN, Wang Y, Timko MP, Ge S, Fan L, Lu Y. 2017. Genomic Variation Associated with Local Adaptation of Weedy Rice During Dedomestication. Nature Communications, 8(1), 1-12.

[13] Frison EA, Cherfas J, Hodgkin T. 2011. Agricultural Biodiversity Is Essential for a Sustainable Improvement in Food and Nutrition Security. Sustainability, 3: 238-253

[14] Bhandari HR, Bhanu AN, Srivastava K, Singh MN, Shreya, Hemantaranjan A. 2017. Assessment of Genetic Diversity in Crop Plants - An Overview. Adv Plants Agric Res, 7(3): 00255

[15] Olatoye, M.O., S.R. Marla, Z. Hu, S. Bouchet, R. Perumal, and G.P. Morris. 2020. Dissecting Adaptive Traits with Nested Association Mapping: Genetic Architecture of Inflorescence Morphology in Sorghum. G3:Genes, Genomes, Genetics, Vol. 10 (5) : 1785 1796.

[16] Suzuki, D.T., J.F. Anthony, Griffiths , J. H. Miller, R.C. Lewontin. 1989. Introduction to Genetic Analysis $4^{\text {th }}$ Edition. W.H. Freeman. 